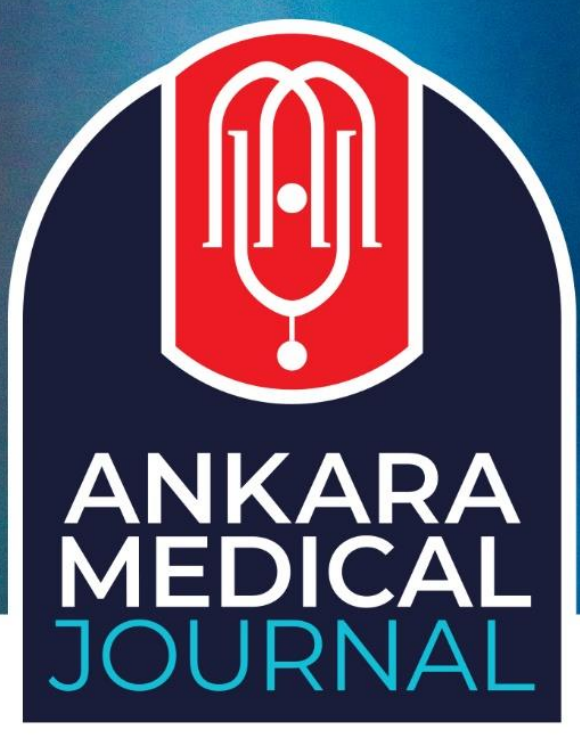

Research Article

Ankara Med J, 2020;(1):144-152 // đoi 10.5505/amj.2020.76768

\title{
THE SPIROMETRY AND THE PEAK-FLOW METER USAGE STATUS OF TURKISH FAMILY PHYSICIANS: A DESCRIPTIVE STUDY
}

\section{TÜRKIYYE'DEKİ AİLE HEKIMLERİNIN SPİROMETRİ VE PEAK- FLOW METRE KULLANMA DURUMLARI: TANIMLAYICI BİR ARAŞTIRMA}

(D) Hatice Küçükceran1, (D) Ezgi Agadayı2, (D) Hülya Vatansev3, (D) İrfan Şencan4

${ }^{1}$ Necmettin Erbakan University, Meram Medicine Faculty Hospital, Department of Family Medicine,

Konya

${ }^{2}$ Cumhuriyet University Medicine Faculty Hospital, Department of Medical Education, Sivas ${ }^{3}$ Necmettin Erbakan University Meram Medicine Faculty Hospital, Department of Chest Diseases, Konya 4 University of Health Science, Ankara Numune Training And Research Hospital, Department of Family Medicine, Ankara

Yazışma Adresi / Correspondence:

Hatice Küçükceran (e-posta: drhaticeran@gmail.com)

Geliş Tarihi (Submitted): 11.09.2019 // Kabul Tarihi (Accepted): 16.01.2020

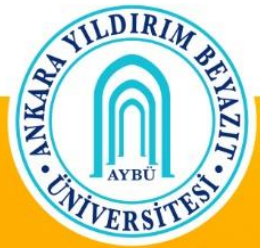

Ankara YIIdırım Beyazıt University Faculty of Medicine Department of Family Medicine 


\section{Öz}

Amaç: Solunum fonksiyon testleri, aile hekimliği pratiğinde gerekli ve uygulanabilir bir yöntemdir. $\mathrm{Bu}$ çalışmadaki amacımız, Türkiye'de aile hekimleri tarafından spirometre veya peak-flow metre cihazlarının kullanım oranlarını ve kullanımlarında etkili olan faktörleri belirlemektir.

Materyal ve Metot: Tanımlayıcı çalışmamıza, Türkiye'deki aile hekimliği sisteminde görev alan hekimler dahil edildi. Hekimlere e-posta yolu ile anketler gönderildi. Geri dönüşlere göre iki aylık bir sürede (Mayıs 2018Temmuz 2018) yeterli örneklem sayısına ( $\mathrm{N}=380$ ) ulaşıldığında çalışma sonlandırıldı.

Bulgular: Hekimlerin \%81,50 ( $\mathrm{n}=310)$ 'sinde peak-flow metre, \%15,50 (n=59)'sinda spirometre vardı. Hekimleri \%11 ( $n=42)$ 'inde ise her iki cihaz da mevcut değildi. Hekimlerin \%66,30 (n=252)'u spirometre ya da peak-flow metre kullanmadığını belirtirken \%6.60'ı $(n=25)$ peak-flow metre kullandığını, \%3.7 (n=14)'si spirometre kullandığını belirtti. Mevcut cihazları kullanmama sebepleri sorulduğunda; en sık sebep aile hekimliği uygulamasında testlerin etkin olmadığını düşünmeleri, ikinci en sık sebep ise nasıl kullanılacağının bilinmemesi idi. Hekimlerin \%79,7 ( $\mathrm{n}=303)$ 'sinin spirometre ve peak-flow metre hakkında bir kursa katılmak istediği tespit edildi.

Sonuç: Aile hekimliğinde bulundurulması zorunlu olan peak-flow metre veya spirometre cihazlarının kullanım oranlarının çok düşük olduğu tespit edildi. Birinci basamakta daha iyi bir hizmet verebilmek için hem tıp fakültesinde hem de mezuniyet sonrası bu konu ile ilgili eğitimlere daha çok ihtiyaç vardır.

Anahtar Kelimeler: Spirometre, peakflow-metre, aile hekimliği, akciğer hastalıkları

\footnotetext{
Abstract

Objectives: Pulmonary function tests are a necessary and applicable method in the practice of family medicine. Our aim in this study was to determine the utilization rates of spirometry or peak-flow meter devices among family physicians who work in Turkey and the factors that influence this usage.

Materials and Methods: This descriptive study included physicians working in the family medicine system in Turkey. Surveys were sent to physicians via e-mail. When a sufficient number of responses $(n=380)$ were obtained in two months (May 2018-July 2018), the study was terminated.

Results: Among the responding physicians, $81.50 \%(\mathrm{n}=310)$ had a peak-flow meter and $1.50 \%(\mathrm{n}=59)$ had a spirometer, while $11 \%(\mathrm{n}=42)$ of the physicians had neither of these devices. On the other hand, $66.30 \%$ $(n=252)$ of the physicians stated that they did not use the spirometer or peak-flow meter, $6.60 \%(n=25)$ used the peak-flow meter, and $3.70 \%(n=14)$ used the spirometer. When asked about the reasons for not using the existing devices, the most common reason was that they thought that the tests were not effective in family medicine and the second most common reason was not knowing how to use them. It was found that, $79.70 \%$ $(n=303)$ of physicians requested a course on spirometry and peak-flow meter.

Conclusion: It was determined that the usage rates of peak-flow meter or spirometry devices, which are required in family medicine, are very low. In order to provide better service in primary care, more training is needed, both in medical faculties and after graduation.

Keywords: Spirometry, peak-flow meter, family physicians, pulmonary disease.
} 


\section{Introduction}

Asthma is a heterogeneous disease characterized by chronic airway inflammation.1,2 Chronic obstructive pulmonary disease (COPD) is a disease that is associated with the increased chronic inflammatory response of airways and lungs in the presence of harmful gases and particles. COPD is commonly characterized by progressive and permanent airflow restriction. ${ }^{3}$ COPD guidelines highlight the importance of physical examination and pulmonary function tests for the correct diagnosis of the disease, as well as the choice of treatment. ${ }^{1-5}$ Forced vital capacity (FVC) and forced expiratory volume in the first second (FEV ${ }_{1}$ ) can be useful for differentiating obstructive and restrictive diseases. ${ }^{3}$ However, when using a peak-flow meter, only peak expiratory flow (PEF) is measured. An average daily PEF variability of greater than $10 \%$ is one of the diagnostic criteria for asthma. ${ }^{1-5}$ However, since the correlation between FEV1 and PEF is not good, it is not recommended that it be used in COPD follow-up. ${ }^{6} \mathrm{~A}$ report by the Turkish Thoracic Society proposed that physicians evaluate the annual loss of FEV1 by spirometrically measuring patients with stable COPD. ${ }^{7}$ Given that a comprehensive approach to the patient's acute and chronic problems is one of the core competencies of family practice, pulmonary function tests are therefore considered potentially useful and applicable within general family medical practice. ${ }^{8}$

Every student and graduate of medicine in Turkey is expected to be able to use a peak-flow meter and perform pulmonary function tests.

The family practice system was introduced in Turkey in 2005. However, there is currently no referral system in health care. Patients can apply to a health facility whenever they want. In this system, various arrangements are made with the aim of providing a certain level of standardization across all institutions. In this context, having a spirometry or peak-flow meter in family practices became mandatory with the new regulations in 2017. The aim of this study was to determine the use of a spirometer or peak-flow meter by family physicians in Turkey and the factors affecting that usage.

\section{Materials and Methods}

The target population of this study comprised 24,428 family practices across Turkey. It is aimed to reach 378 people with a 95\% confidence interval and a 5\% margin of error using the formula for Sample Size for Finite Universe $\left(n=X 2 N P(1-P) \div d 2(N-1)+X 2 P(1-P) .{ }^{9}\right.$ Online questionnaires were sent to family physicians via email. Information about the study together with the voluntary participation form page was made available to the potential subjects prior to the survey's initiation. Participation was voluntary. Physicians working within the family practice system across Turkey who agreed to answer our questionnaire form were included in the 
study. The study was terminated based on the responses when an adequate number of samples ( $\mathrm{n}=380)$ was obtained in two months (May 2018-July 2018).

The research is presented as a descriptive study. Ethical approval was obtained from the Clinical Research Ethics Committee of the University of Health Sciences, Ankara Numune Training and Research Hospital, with decision number 1828 dated 08.03.2018. In addition, on 04.04.2018 (number: 49654233-604.2), permission was obtained from the General Directorate of Public Health of Ankara.

The survey questions addressed the following variables:

- Gender.

- Age.

- How many years he/she has worked as a family physician.

- The province and district in which the physician works.

- How many patients the physician examines per day.

- How many asthma-COPD patients the physician examines per week.

- Is there a chest disease specialist working close by/far away to whom he/she can refer?

- Has the physician received training on the use of the spirometer and peak-flow meter?

- If the physician did receive such training, where was it received?

- Is there a spirometer or a peak-flow meter in the physician's unit?

- How does the physician decide to use either a spirometer or peak-flow meter?

- We wrote six indications for spirometer usage and asked them to answer "true" or "false".

- We wrote five indications for peak-flow meter usage and asked them to answer "true" or "false".

- If the physician does not use either of these devices, then why, and would he/she like to receive education?

The collected data were analyzed with a statistics software package (SPSS for Windows 18). The Shapiro-Wilk test was used to determine if the data had a normal distribution. Collected data were first used for descriptive statistics. Frequencies for categorical variables and measures of central tendency (mean \pm standard deviation) for continuous variables were calculated. For data with non-normal distribution, the Mann-Whitney U test was used to compare two independent groups. The chi-square test was used to analyze the categorical data. A pvalue of less than 0.05 was considered for statistical significance with a $95 \%$ confidence interval. 


\section{Results}

Of the participants, $54.50 \%(n=207)$ were female and $45.50 \%(n=173)$ were male. The participants' titles were general practitioner (GP; 75.80\%, $\mathrm{n}=288$ ), family medicine specialist (FM; 21.30\%, $\mathrm{n}=81$ ), and other field specialist $(2.90 \%, \mathrm{n}=11)$, respectively. The majority of the physicians $(65.80 \%, \mathrm{n}=250)$ worked in city centers, whereas $34.20 \%(n=130)$ worked in rural areas. The geographical regions in which the participants worked are shown in Figure1. There was no significant relation between physicians' geographical regions and the use of pulmonary function tests $(\mathrm{p}=0.300)$. Furthermore, no significant difference was found between physicians' working areas (city center/rural area) and the use of pulmonary function tests $(\mathrm{p}=0.068)$.

The mean of the participants' numbers of daily examinations was $46.90 \pm 18.60$. The mean number of asthma or COPD patients that they said they examined per week was $10.20 \pm 9.50$. There was no significant difference between the daily number of patients examined and the use of pulmonary function tests $(p=0.480)$.

It was stated by $80.30 \%(n=305)$ of the participants that there was a chest disease specialist nearby. No significant difference was found between the availability of a chest disease specialist and the use of pulmonary function tests $(\mathrm{p}=0.471)$.

Additionally, 32.10\% ( $\mathrm{n}=122)$ of the participants had received spirometry education and $28.40 \%(\mathrm{n}=108)$ had received education about peak-flow meters. Participants received that spirometry education in medical school $(30.50 \%, n=116)$, during residency training $(9.50 \%, n=36)$, via a personal literature review $(5.50 \%, n=21)$, during special courses or congresses $(4.20 \%, \mathrm{n}=16)$, and in courses conducted by the Ministry of Health $(1.30 \%$, $n=5$ ), respectively. Those who received spirometry education in medical school were significantly younger than those who did not $(\mathrm{p}<0.001)$. The mean age of those who received such education in medical school was $33.70 \pm 5.10$ years, whereas the mean age of those who did not receive such training during medical school was $37.40 \pm 7.20$. Table 1 shows a comparison of the use of peak-flow meter/spirometer and the institutions in which the participating physicians received this education. Table 2 shows a comparison of knowledge about peak-flow meter/spirometer indications and the institutions in which they received this education.

Of the participating physicians, $11.10 \%(\mathrm{n}=42)$ did not have any devices for pulmonary function tests. The rate of participants who had only a peak-flow meter was $73.40 \%(n=279)$, while $8.20 \%$ had both a peak-flow meter and spirometer $(n=31)$ and $7.40 \%$ had only a spirometer $(n=28)$. The reasons for physicians to choose their devices included low price $(74.70 \%, \mathrm{n}=284)$, ease of use $(16.60 \%, \mathrm{n}=63)$, and extensive usage indications $(1.80 \%, \mathrm{n}=7)$, respectively. 
The mean of the number of correct answers for spirometry indications among the participants was 3.50 \pm 1.90 . The mean of correct responses for peak-flow meter indications was $2.80 \pm 1.30$. The responses of the participants regarding spirometry and peak-flow meter indications are shown in Table 3.

Only 6.60\% (n=25) of the participants stated that they used their peak-flow meter in the follow-up of asthma patients, while $2.40 \%(n=9)$ used it in the follow-up of COPD patients. Furthermore, 3.70\% (n=14) reported that they used spirometry in the follow-up of patients with asthma and COPD, and 66.30\% ( $\mathrm{n}=252)$ did not use a spirometer or peak-flow meter. The rate of physicians who said that they direct patients suspected of asthma or COPD to a pulmonologist was $54.70 \%(n=208)$. The reasons for not using a spirometer or peak-flow meter are shown in Table4.

When training needs were asked,79.70\% (n=303) of participants stated that they would like to attend a course on spirometry and peak-flow meter usage aimed at family medicine practitioners and organized by the Ministry of Health.

Table 1. Comparison of the use of peak-flow meter/spirometer and the institution in which that education was received

\begin{tabular}{|l|c|c|c|}
\hline \multirow{2}{*}{ Medical school } & \multicolumn{2}{|c|}{ Usage status, \% (n) } & \multirow{2}{*}{ p } \\
\cline { 2 - 3 } & Not using & Using & 0.246 \\
\hline Specialization training & $62.10 \%(72)$ & $37.90 \%(44)$ & 0.246 \\
\hline Special courses and congresses & $44.40 \%(16)$ & $55.60 \%(20)$ & 0.004 \\
\hline Personal literature review & $18.80 \%(3)$ & $81.30 \%(13)$ & $<0.001$ \\
\hline Courses organized by the Ministry of Health & $71.40 \%(15)$ & $28.60 \%(6)$ & 0.610 \\
\hline No education & $40 \%(2)$ & $60 \%(3)$ & 0.764 \\
\hline
\end{tabular}

Table2. Comparison of knowledge about peak-flow meter/spirometer indications and the institution in which that education was received

\begin{tabular}{|l|c|c|c|c|c|c|}
\hline & \multicolumn{2}{|c|}{$\begin{array}{c}\text { Knowledge of } \\
\text { spirometer indications } \\
\text { Mean } \pm \text { SD }\end{array}$} & \multirow{2}{*}{$\mathbf{p}$} & \multicolumn{2}{|c|}{$\begin{array}{c}\text { Knowledge of peak-flow } \\
\text { meter indications } \\
\text { Mean } \pm \text { SD }\end{array}$} & \multirow{2}{*}{$\mathbf{p}$} \\
\cline { 2 - 3 } & $\begin{array}{c}\text { Received } \\
\text { education }\end{array}$ & $\begin{array}{c}\text { Not } \\
\text { received } \\
\text { education }\end{array}$ & & $\begin{array}{c}\text { Received } \\
\text { education }\end{array}$ & $\begin{array}{c}\text { Not } \\
\text { received } \\
\text { education }\end{array}$ & \\
\hline Medical school & $4.20 \pm 1.80$ & $3.10 \pm 1.90$ & $<0.001$ & $3.30 \pm 1.70$ & $2.60 \pm 1.50$ & $<0.001$ \\
\hline Specialization training & $4.10 \pm 1.70$ & $3.40 \pm 1.90$ & 0.046 & $3.10 \pm 1.40$ & $2.80 \pm 1.60$ & 0.212 \\
\hline $\begin{array}{l}\text { Special } \\
\text { courses/congresses }\end{array}$ & $4.30 \pm 1.70$ & $3.40 \pm 1.90$ & 0.086 & $3 \pm 1.60$ & $2.80 \pm 1.60$ & 0.636 \\
\hline $\begin{array}{l}\text { Personal literature } \\
\text { review }\end{array}$ & $4.20 \pm 2$ & $3.40 \pm 1.90$ & 0.091 & $3.20 \pm 1.60$ & $2.80 \pm 1.60$ & 0.272 \\
\hline $\begin{array}{l}\text { Courses organized by the } \\
\text { Ministry of Health }\end{array}$ & $2.80 \pm 1.40$ & $3.50 \pm 1.90$ & 0.449 & $2.60 \pm 1.10$ & $2.80 \pm 1.60$ & 0.864 \\
\hline
\end{tabular}


Table 3. Participants' responses to spirometer and peak-flow meter indications

\begin{tabular}{|c|c|c|c|}
\hline & & Yes, \% (n) & No, \% (n) \\
\hline \multirow{6}{*}{ 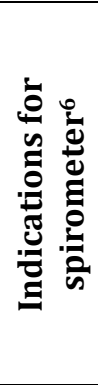 } & *To evaluate symptoms, signs, or abnormal laboratory tests & $80 \%(304)$ & $20 \%(76)$ \\
\hline & $*$ To measure the effect of disease on pulmonary function & $67.60 \%(257)$ & $32.40 \%(123)$ \\
\hline & $\begin{array}{l}\text { * To assess health status before beginning strenuous physical } \\
\text { activity programs }\end{array}$ & $49.70 \%(189)$ & $50.30 \%(191)$ \\
\hline & $\begin{array}{l}* \text { To assess therapeutic intervention (bronchodilator or steroid } \\
\text { treatment, etc.) }\end{array}$ & $63.70 \%(242)$ & $36.30 \%(138)$ \\
\hline & ${ }^{*}$ To assess the prognosis of a disease & $50.30 \%(191)$ & $49.70 \%(189)$ \\
\hline & $\begin{array}{l}* \text { Monitoring for adverse reactions to drugs with known } \\
\text { pulmonary toxicity }\end{array}$ & $38.40 \%(146)$ & $61.60 \%(234)$ \\
\hline \multirow{5}{*}{ 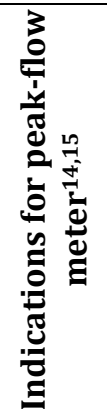 } & * To diagnose asthma & $76.60 \%(291)$ & $23.40 \%(89)$ \\
\hline & * To diagnose COPD & $30 \%(114)$ & $70 \%(266)$ \\
\hline & ${ }^{*}$ To assess the response to treatment & $62.90 \%(239)$ & $37.10 \%(141)$ \\
\hline & *To determine asthma attacks & $37.90 \%(144)$ & $62.10 \%(236)$ \\
\hline & *To monitor asthma self-management plans for patients & $38.90 \%(148)$ & $61.10 \%(232)$ \\
\hline
\end{tabular}

Note: False suggestion is indicated in bold font; all others are correct.

Table 4. Reasons for not using spirometer or peak-flow meter

\begin{tabular}{|l|c|}
\hline & $\%(\mathrm{n})$ \\
\hline I don't think the use of these tests is effective in family practice & $53.70 \%(204)$ \\
\hline I don't know how to use them & $38.20 \%(145)$ \\
\hline I can't find the opportunity to use them due to intense work pressure & $26.80 \%(102)$ \\
\hline Other* & $4.90 \%(19)$ \\
\hline
\end{tabular}

*: Due to the lack of medication reimbursement, not wanting to use them, and being afraid of harming patients.

\section{Conclusion}

According to the results of our study, $82 \%$ of the participants had a peak-flow meter, $16 \%$ had a spirometer, and $11 \%$ had neither. The rate of use of these devices was very low (peak-flow meter: 6.60\%, spirometer: $3.70 \%$ ). A Belgian study by Boffin et al. revealed that 38\% of family physicians had a spirometer, and $17 \%$ used them, while $70 \%$ had used a peak-flow meter. ${ }^{8}$ Dowson et al. showed that $21 \%$ of primary care physicians in the region of Staffordshire had a spirometer and that $12 \%$ had used them. ${ }^{10}$ Another British study by Bolton et al. revealed that $82 \%$ of family physicians had a spirometer and that $86 \%$ of those physicians used the device in daily practice. ${ }^{11}$ An American study by 0'Dowd et al. reported that $49 \%$ of family physicians had a spirometer and $15 \%$ of the physicians with a spirometer said that they had never used it, whereas $42 \%$ rarely used it. ${ }^{12}$ 
The frequency of spirometer use among family physicians varies widely in different parts of the world; however, in our study, the use of spirometry was found lower when compared to the literature.

Nearly half (54\%) of those who did not use a spirometer or peak-flow meter did not use these tests because they felt that they were ineffective in family practice. The second most common reply (38\%) was that they did not know how to use them. Boffin et al. showed that $68 \%$ of physicians felt that spirometry was a task of family physicians, while the biggest obstacles hindering its use were cited as time shortages and a lack of knowledge and skills. ${ }^{8}$ Vanjare et al. reported that the most frequent reasons for not using these devices were that the devices were far too expensive, so the patients had difficulty paying for these tests, and time was limited in the clinic. ${ }^{13}$

All doctors who graduate from medical school in Turkey should be able to use a peak-flow meter and evaluate pulmonary function tests. The age of the participating physicians who received spirometry training in medical faculties was found to be lower than non-trained group. It can be said that within the curriculum of medical faculties, spirometry training has been given more importance in recent years. According to our results, undergraduate spirometry and the peak-flow meter usage training did not affect postgraduate usage. So, it can be interpreted as the training received in the medical faculties had no significant impact on the usage status. Practical training should, therefore, be increased in medical faculties. In our study, 80\% of the physicians stated that they wanted training organized by the Ministry of Health. This is supported by evidence that $62 \%$ of the physicians felt that more training would be beneficial. ${ }^{8}$

Patients with COPD often have few symptoms at the onset of the disease. ${ }^{4}$ Those living in rural areas who struggle to reach a chest disease specialist will instead go to family physicians. In our study, $19.7 \%$ of participants reported the lack of a chest disease specialist in their regions. Therefore, we can conclude that it is important to understand and use spirometry devices, especially for this reason.

In our study, the median number of asthma or COPD patients examined weekly by our participants was 8. In the study by O'Dowd et al., 50\% of the participants stated that fewer than five asthma patients were examined per week. In the same study, about half of the physicians owned a spirometer and $82 \%$ of them used it. ${ }^{12}$ In our study, the rate of use of spirometry was quite low in proportion to the relatively high number of patients being examined.

Family physicians in Turkey are obliged to have either a spirometer or a peak-flow meter, but the usage rate was found to be lower in comparison to the examined medical literature. The most important reasons for this situation were the belief in the ineffectiveness of these devices in the context of family practice and the lack of knowledge. The Ministry of Health, together with other medical associations, should organize a certified training program for these devices. Furthermore, these associations or the Ministry should issue 
unambiguously written and comprehensible guides that cover topics such as the use of spirometers and peakflow meters specifically for primary care physicians, indications for use, the suitability of the devices, and the test procedures. Once these goals are accomplished, it will be possible for family physicians to achieve standardization, and the usage rates of these devices will increase.

\section{Limitations of the Study}

As this study was conducted online, we could not reach physicians who do not use email very often or at all. Another limitation of our study was that no randomization was possible as participation was voluntary.

\section{References}

1. Türk Toraks Derneği astım allerji çalışma grubu. Türk Toraks Derneği astım tanı ve tedavi rehberi 2016 güncellemesi-Bölüm 1: Tanım ve genel bakış. Turkish Thoracic Journal 2016;17(1):1-5.

2. Parlak A, Arık D, Aydoğan Ü. Birinci basamakta erişkin astım yönetimi. Smyrna Tıp Dergisi 2012;2(1):39-44.

3. Türk Toraks Derneği KOAH çalışma grubu. Kronik obstrüktif akciğer hastalığı (KOAH) koruma, tanı ve tedavi raporu 2014-Bölüm 1: Tanımlama ve hastalığa genel bakış. Turkish Thoracic Journal 2014;15(2):1-12.

4. Global initiative for chronic obstructive lung disease. Pocket guide to COPD diagnosis, management, and prevention a guide for health care professionals 2018 edition. [İnternet]: https://goldcopd.org/wp-content/uploads/2018/02/WMS-GOLD-2018-Feb-Final-to-print-v2.pdf (Erişim tarihi:06.09.2019).

5. Global initiative for asthma. Pocket guide for health professionals updated 2016. [İnternet]:https://ginasthma.org/wp-content/uploads/2016/05/WMS-GINA-2016-main-PocketGuide.pdf (Erişim tarihi 06.09.2019).

6. Miller MR, Hankinson J, Brusasco V et al. Standardisation of spirometery. European Respiratory Journal 2005;26(2):319-38.

7. Türk Toraks Derneği KOAH çalışma grubu. Kronik obstrüktif akciğer hastalığı (KOAH) koruma, tanı ve tedavi raporu 2014- Bölüm6: KOAH’lı hastanın izlemi. Turkish Thoracic Journal 2014;15(2):72-6.

8. Boffin N, Van der Stighelen V, Paulus D, Van Royen P. Use of office spirometers in Flemish general practice: results of a telephone survey. Monaldi Archives for Chest Disease 2006;65(3):128-32.

9. Sümbüloğlu K, Sümbüloğlu V. Biyoistatistik. 12. Baskı, Ankara: Hatipoğlu yayın evi; 2012.

10. Dowson LJ, Yeung A, Allen MB. General practice spirometer in North Stafford shire. Monaldi Archives for Chest Disease 1999;54:186-8. 
11. Bolton CE, Ionescu AA, Edwards PH, Faulkner TA, Edwards SM, Shale DJ. Attaining a correct diagnosis of COPD in general practice. Respiratory Medicine 2005;99:493-500.

12. O’Dowd L, Fife D, Tenhave T, Panettieri R. Attitudes of physicians toward objective measures of airway function in asthma. The American Journal of Medicine 2003;114:391-6.

13. Vanjare N, Chhowala S, Madas S, Kodgule R, Gogtay J, Salvi S. Use of spirometer among chest physicians and primary care physicians in India. NPJ Primary Care Respiratory Medicine 2016;26:16036.

14. Adeniyi BO, Erhabor GE. The peak flowmeter and its use in clinical practice. African Journal of Respiratory Medicine 2011;6(2):5-8.

15. Sağlık Bakanlığı [İnternet]. https://hsgm.saglik.gov.tr/depo/birimler/kronik-hastaliklar-engelli$\mathrm{db} /$ hastaliklar/kronik_havayolu/rehberler/Astim_KOAH_Egitimci_Rehberi.pdf (Erişim tarihi: 19.12.2019). 